Research paper

\title{
Improving stock unearthing method to measure soil erosion rates in vineyards
}

\author{
Jesús Rodrigo-Comino ${ }^{\mathrm{a}, \mathrm{b}, *}$, Artemi Cerdàc \\ a Instituto de Geomorfología y Suelos, Department of Geograpy, University of Málaga, 29071, Málaga, Spain \\ b Physical Geography, Trier University, 54286 Trier, Germany \\ c Soil erosion and Degradation Research Group, Department of Geography. University of Valencia, 46010 Valencia, Spain
}

\section{A R T I C L E I N F O}

\section{Keywords:}

Vineyards

Soil erosion indicator

Improved stock unearthing method

Connectivity

\begin{abstract}
A B S T R A C T
Vineyard soils experience high erosion rates compared to soils from other agricultural land uses. The high soil losses in vineyards limits the sustainability of traditional production schemes and warrants comprehensive research aimed at thwarting the main erosion processes affecting vineyard systems. However, long-term measurements, which include spatial variability of soil erosion rates at the plot scale, are uncommon, as most of the measurements have taken place either at the hillslope or watershed scales. Against this background, the stock unearthing method (SUM) can be considered a useful methodology. However, the current method falls short because it assumes that the topography between the vine lines (inter-rows) remains planar. Therefore, we propose a new methodology (ISUM: improved stock unearthing method) that includes three measurements between in the inter-row areas. By taking inter-row measurements, we hypothesized that the spatial patterns of sediment detachment, transport and deposition features in the inter-rows would be detected. The ISUM costs $20 \%$ more time to conduct than the SUM, but greatly improved the utility of the field survey. ISUM allowed for: i) the creation of maps that identified linear soil erosion features and accumulation sites; ii) measures the amount of soil accumulated under the vines; iii) estimation of soil erosion rates with higher accuracy at long-term periods in a specific moment. This study compared the ISUM with the SUM in a vineyard in Spain. Soil erosion

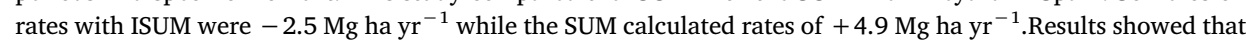
the traditional method underestimated soil rates a $-25.7 \%$. Maps created with the ISUM technique could also be used to provide insights about sediment connectivity.
\end{abstract}

\section{Introduction}

Many vineyards have exceeded their ecological limits as they often occupy lands with critical natural conditions such as steep slopes, shallow and rocky soils and dry climatic conditions, factors that may induce high soil erosion rates (Molinero Hernando, 2012; Prosdocimi et al., 2016; Vaudour et al., 2017). The high erosion rates found in vineyards threaten the goods and services that soils offer to humans (Mol and Keesstra, 2012; Brevik et al., 2015) and undermine the United Nations goals of reaching sustainability (Keesstra et al., 2016a). However, viticulture areas remain economically and socially relevant and are often highly appreciated for their cultural heritage (Koch et al., 2013; Lourenço-Gomes et al., 2015). They are often targeted as landscape which should be protected (Leeuwen van et al., 2004; MartínezCasasnovas et al., 2010).

Soil erosion on vineyards threatens the sustainability of the vine production system (Martínez Casasnovas and Ramos, 2006). Verheijen et al. (2009) defined tolerable erosion rates in the fields where degradation or loss of "one or more soil functions does not occur", meaning in Europe from 0.3 to $1.4 \mathrm{Mg} \mathrm{ha}^{-1} \mathrm{yr}^{-1}$. However, in vineyards, this limit is widely surpassed. For example, Martínez-Casasnovas et al. (2003) summarized total average net erosion of $576 \mathrm{Mg} \mathrm{ha}^{-1}$ $\mathrm{yr}^{-1}$ within their study period (1975-95) in a gully close to a vine plantation. Cerdan et al. (2010) using a meta-analysis quantified a total average net erosion for European vineyards of $8.62 \mathrm{Mg} \mathrm{ha}^{-1} \mathrm{yr}^{-1}$. In Italy, in Sicilian vineyards, Novara et al. (2011) using the pin erosion method measured erosion rates of as high as $102 \mathrm{Mg} \mathrm{ha}^{-1} \mathrm{yr}^{-1}$.

Traditional vineyards are commonly planted along contour lines or contain small terraces with moderate slopes, which are supported by long rows of plants (Ramos and Porta, 1997; Sofia and Tarolli, 2017). Both of these systems lead to increased grape and wine productions, but may consequently enhance land and ecosystem degradations due to accelerated soil erosion, intense ploughing, use of pesticides, herbicides and fungicides (López-Piñeiro et al., 2013; Salomé et al.,2016).

\footnotetext{
* Corresponding author at: Instituto de Geomorfología y Suelos, Department of Geograpy, University of Málaga, 29071, Málaga, Spain.

E-mail address: rodrigo-comino@uma.es (J. Rodrigo-Comino).
} 
Extreme rainfall events are also major drivers that cause high erosion rates. But a lack of vegetation (grass or shrub) and, or litter cover (García-Díaz et al., 2017; Novara et al., 2011; Rodrigo-Comino et al., 2017a) or the use of heavy machinery (Bogunovic et al.. 2017; Ferrero et al., 2005) can also enhance soil erosion processes. In this way, land management strategies in vineyards can be seen as abusive of soil resources, as they increase the risk of catastrophic floods, non-point pollution of chemicals caused by excessive overland flow and decrease of water and nutrient availability for the vines (Calleja-Cervantes et al., 2015; Leonard and Andrieux, 1998). Nowadays, there is a growing awareness of these issues, which has resulted in research aimed to reduce soil losses by means of soil and water conservation strategies (Martínez Casasnovas and Sánchez-Bosch, 2000; Cerdà et al., 2017a). Moreover, recently, new studies quantify and confirm that vineyards are not sustainable since the initial planting due to the impact on soil properties (Cerdà et al., 2017b; Rodrigo-Comino et al., 2017b).

The negative impacts registered at the intra-plot scale in soil erosion (e.g. rills, soil properties, etc.) in vineyards is well known by researchers (Chevigny et al., 2014; Rodrigo-Comino et al., 2016a) and farmers alike (Bramley and Hamilton, 2004; Marques et al., 2015). This has necessitated the development of cheap and easily applied measurement methods that are able to survey spatial and temporal topographical changes in the landscape. Such methods can consequently foresee the development of rills and gullies, which are the principal landscape features leading to the more extreme erosion rates in agriculture lands (Defersha et al., 2011). Most research regarding intra plot variabilities has been focused on short-term (years) time periods. Longterm scale (decades) field measurements, though often claimed to be necessary, are rare, while the information derived from long-term measurements is fundamental to developing and selecting suitable land management plans (Keesstra et al., 2016b) and the sources can be heterogeneous (Smith et al., 2015). Performing long-term topographic measurements of vineyards has proven to be both difficult and costly (De Sy et al., 2013). Therefore, there has been a need to develop longterm measurement techniques to address these demands.

The stock unearthing method (SUM) has been shown to be a reliable method to estimate erosion rates and spatial distribution of the topsoil from pluri-annual to pluri-decennial time scales in vineyards (Brenot et al., 2008; Casalí et al., 2009; Paroissien et al., 2010). This method is similar to a dendro-geomorphological method which is based on the measurement of the distance from the topsoil to the grafted vine stock union. The graft union has been confirmed as a passive indicator of topsoil movements since the initial planting of vine stock. This method is able to estimate erosion rates at temporal scales sufficiently long to evaluate the cumulated effects of tillage practices, but also to show the spatial distribution of the sediment detachment, transport and deposition under natural rainfall events within a specific time frame.

Significant changes in topsoil level caused by the impact of rainfall events and soil tillage practices in traditionally managed vineyards can lead to land degradation processes by decreasing soil quality, nutrient and water losses or pollutant transports (Blavet et al., 2009; García-Díaz et al., 2017). To assess changes in soil level, stock unearthing method (SUM) has been a useful method because: i) it is relatively easy to be applied; ii) it generates accurate data which are representative of longterm periods of soil erosion rates; and, iii) it is an easily reproducible tool which can generate the production of a very high actual DEM resolution $(\mathrm{cm})$ without drones or planes. The papers published by Brenot et al. (2006,2008), Casalí et al. (2009), Paroissien et al. (2010), Chevigny et al. (2014) and Quiquerez et al. (2014) as well as the most recent by Rodrigo-Comino et al. (2016b) and Biddoccu et al. (2017) have not only provided estimates of soil erosion rates and identified the main factors responsible for intra-plot variability, but have generated new information for the education of the stakeholders about the environmental issues.

The most recent studies have tested the SUM accuracy by comparing SUM results with digital elevation models, GPS, orthophotography
(Biddoccu et al., 2017; Chevigny et al., 2014; Quiquerez et al., 2014) or with data generated from sediment collectors (Rodrigo-Comino et al., 2016b). However, all of these studies assumed the main limitation of this method: the surface between the vines (inter-row) remains planar. In this way, the effect on soil roughness from tillage, rill development, footpaths, and wheel tracks, plus the consolidation of the soil after tillage or since plantation may have been ignored, as these factors lead to uneven topographical characteristics. Soil is constantly reallocated due to the passing of machinery for various purposes, surface washing of materials as well as consolidation of the soil matrix after the tillage. The SUM method should be enhanced to include measurements which incorporate those factors affecting soil movement in the inter-row areas. Those improvements will contribute to a more accurate soil erosion measurement that will end in a more sustainable management and nature based solutions (Keesstra et al., 2018).

Therefore, the main aim of this methodological approach is to develop an improved SUM. Moreover, we tried to maintain the improved method's ease to apply and of low cost. To achieve this, we intensively measured two vine rows of a vineyard in Eastern Spain by applying the newly developed improved stock unearthing method (ISUM), and compared the results with the results garnered from the traditional method (SUM).

\section{Materials and methods}

\subsection{Study area}

We selected a plot from the traditional viticulture region of Terres dels Alforins, in Valencia province (Valencia, Eastern Spain). The experimental area is located in Les Alcusses valley within the Moixent municipality (Fig. 1). The study area is a representative vineyard, located in a colluvial lying area (footslope position) with active erosion processes, including tillage and water soil erosion. The selected rows were considered as representative because they had not been recently tilled and there were clear signals of soil erosion (e.g. rills and sinks).

The plantation belongs to the Celler del Roure winery and is 25years old, with a framework of $3.0 \times 1.4 \mathrm{~m}$. Each row contains approximately 125 and 130 vines $(\approx 175 \mathrm{~m})$. The observed soil profiles reach from 40 to $60 \mathrm{~cm}$ depth and are homogeneous due to millennia old practice of tillage. All the rows and inter-rows receive the same agricultural treatment: tillage (three times per year). The soil texture is sandy-loam. At the surface, the rock fragments cover from 25 to $40 \%$ and from $10 \mathrm{~cm}$ depth, the volume of rock fragments and gravels in the soil profile are lower than $10 \%$.

\subsection{Stock unearthing method: improvements from SUM to ISUM}

The stock unearthing method (SUM) aims to measure the distance between frontal marks on the graft union of vines and the actual soil surface. The unearthed graft union reflects the initial distance between the vine stock and the actual topsoil level at the date of observation. Before the initial vine plantation under which grafting occurred, soil is levelled and the saplings $(30-40 \mathrm{~cm}$ tall by $1-2 \mathrm{~cm}$ diameter grapevine) roots are used inserted into the soil. When manually planting, the graft union is consistently placed at $2 \mathrm{~cm}$ height to allow the vine to avoid complications caused by soil moisture, freezing, and fungi pests. The distance of the graft union to the original soil level has remained constant since the original vine stock does not grow vertically (Brenot et al., 2006; Brenot et al., 2008; Casalí et al., 2009); only the new part corresponding to the new grape variety will grow (Fig. 2a). Therefore, changes from the theoretical initial conditions due to depletion (Fig. 2b) or accumulation (Fig. 2c) of sediments can be estimated. We confirmed with the farmers the unappreciable vertical growth of the graft union after planting and the proof of the initial elevation as constant at a parallel control plot with new vines (initial distance $=2 \mathrm{~cm}$ ). 

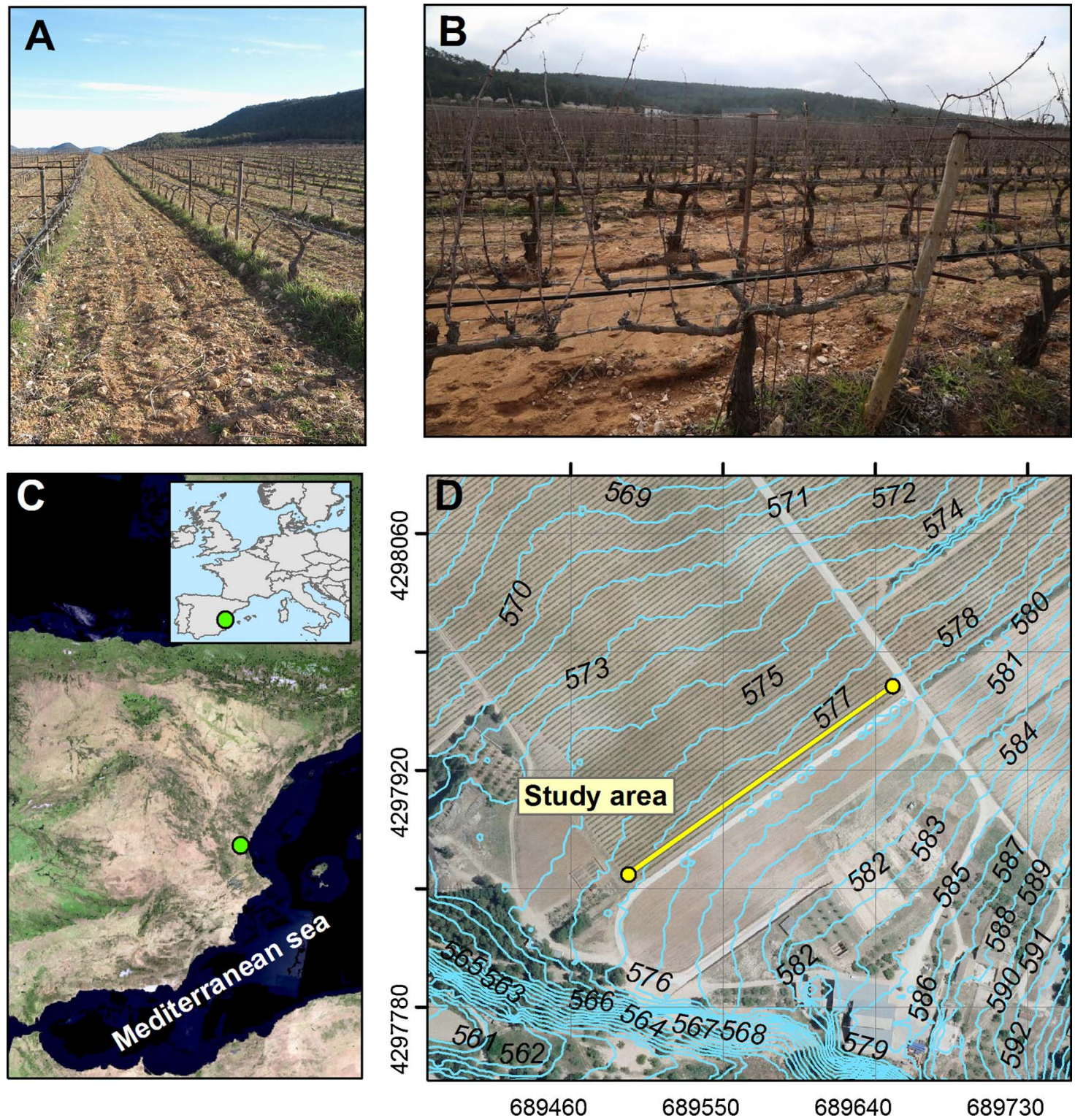

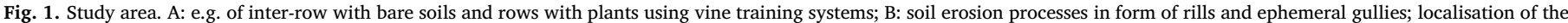
study area in the Iberic territory; D: topographical map and position of the tested row.

The main limit of SUM method is that it was established on the assumption that the topsoil surface between the vine rows remains constantly planar (Fig. 2b and c), without measuring of uncertainty due to roughness by rills, footpaths, and wheel tracks (Fig. 2d).

Therefore, we propose an easy-to-apply and low-cost method to improve both the accuracy and resolution of the SUM by additionally including three measurement points from the inter-row area. For this first methodological approach, we decided to measure three extrapoints because we hypothesized that it should be enough to detect the main deposition and erosion features. To do this, we needed to ensure we could gather consistent and uninhibited measurements. For each measurement row, we first identified the vine graft stock unions (2 vines per measurement) and found the point along the vine stock precisely $30 \mathrm{~cm}$ above the graft union. This allowed for the accurate measurement of inter-row points that were above the graft unions themselves. We then stretched meter tape between these elevated points (Fig. 2e) and used a meter stick to measure the distance between the stretched meter tape and the soil surface between the vines at three locations. To determine the three inter-row measurement points, we delineated two points at $1 \mathrm{~m}$ of distance from the vines and one more, precisely between $(1.5 \mathrm{~m})$ both vines in each row. From these five height measurements, we were able to: i) generate DEMs (digital elevation models) without interpolation methods such as kriging. co-kriging or IDW (Inverse Distance Weighted) by using only measured points; ii) increase the accuracy and precision of our final maps and soil erosion rate estimations; and, iii) detect certain linear erosion processes such as rills, accumulations or mass transports. This provided for evidence of surface runoff as well as subsequent overland sediment flows, directly contributing to understanding the connectivity of sediments and water flows along the slope. We named the updated method Improved Stock Unearthing Method (ISUM).

\subsection{ISUM maps and estimations of soil erosion rates}

We measured the relative soil heights of 200 (100 vines +100 vines paired) graft unions, from the end part of the graft union to the actual topsoil level. The same person took these measurements throughout the study area. If the high soil roughness under the vine showed little steps, rock fragments or the grass cover limited the visibility of the graft union, soil and plants were carefully removed in order to level the soil 


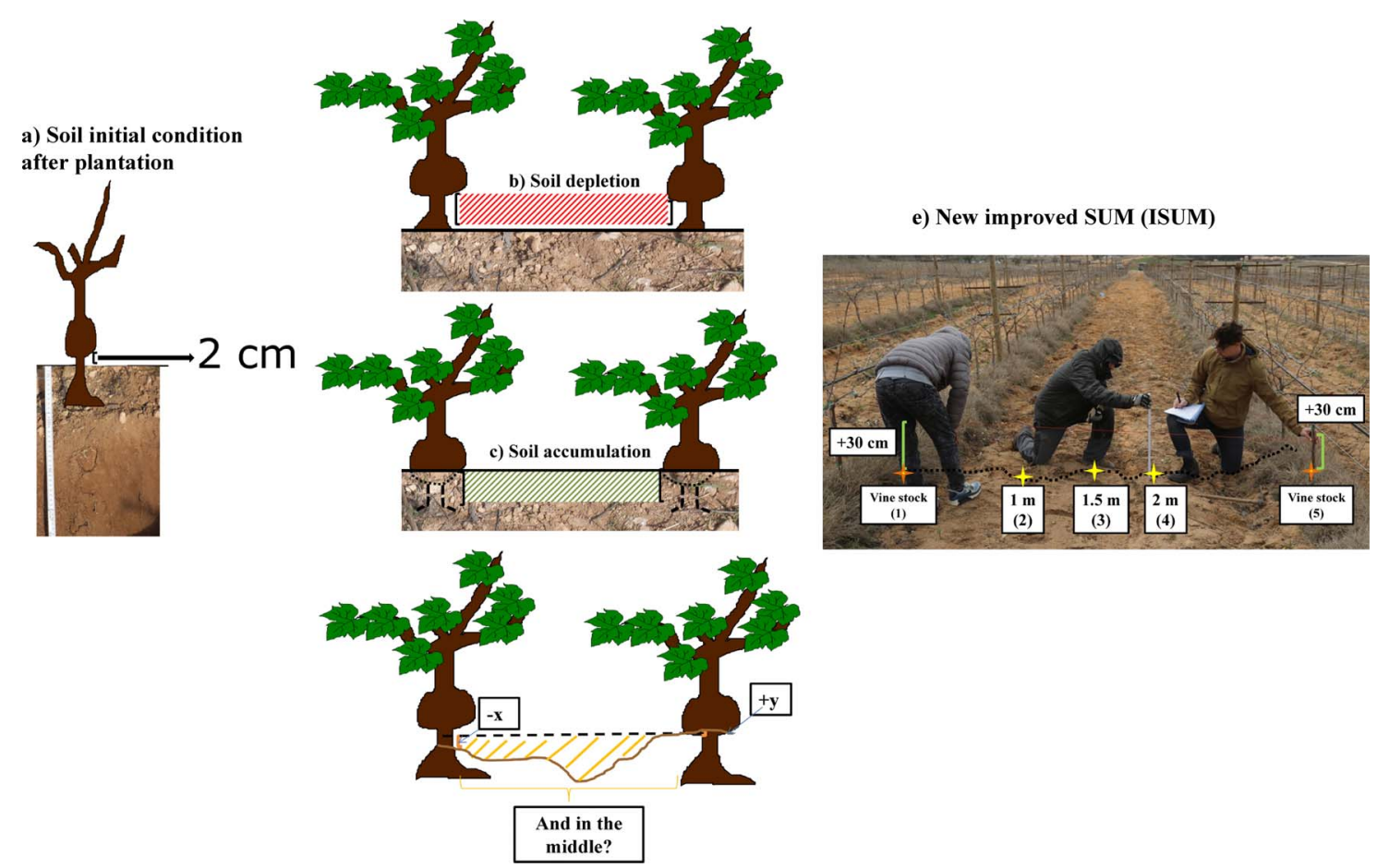

Fig. 2. New improve stock unearthing method (ISUM).

under the vine with the adjacent topsoil level. After measuring the distance between the graft union and topsoil level, three more points were delineated between the vines. Therefore, for every paired grapevine, we measure five points. That meant that DEM maps and soil erosion estimations were carried out using 500 points instead of the 200 that would have been used by the SUM. For the final estimations, an addition of $2 \mathrm{~cm}$ was applied to all the measurements, corresponding to the initial graft union distance.

To represent the actual topsoil level of the surface in 2017 (February), it was incorporated in a grid of points ("fish net") all the measured points in the software ArcMap 10.4 (ESRI). Two imaginary extra points ( $0.5 \mathrm{~m}$ from the graft union) were needed to be created in every measured line in order to obtain a regular grid. After joining the data of the measured points to the shapefile, we generated a digital elevation model (DEM) by using the "Topo to raster" tool (http:// desktop.arcgis.com/en/arcmap/10.3/tools/3d-analyst-toolbox/topoto-raster.htm). This method, which keeps measured values at sample sites, was preferred to other interpolation methods because a smaller root mean square error can be achieved (Dirks et al., 1998; Goovaerts, 1999; Wang et al., 2013). Topo-to-raster is "a discretized thin plate spline technique" (Wahba, 1990) for which the roughness penalty has been modified to allow the fitted DEM to follow abrupt changes in terrain, such as streams, ridges and cliffs (http://desktop.arcgis.com/ en/arcmap/10.3/tools/3d-analyst-toolbox/topo-to-raster.htm)

The resultant map with a resolution of $0.5 \mathrm{~m}$ was used to assess the spatial distribution of erosion processes. The final map was divided in five parts to be able to analyze every erosion feature with more precision.

\subsection{Statistical analysis}

Boxplot graphics of measured points show averages, medians and percentiles (5th and 95th). To compare the results obtained in every line of point measures, one-way ANOVA test was performed for each line of points with Sigma Plot 12.0 (Systat Software Inc.). However, Shapiro-Wilk and equal variance tests did not indicate the data was normally distributed. Therefore, a Mann-Whitney $U$ test was carried out, where significant differences at $\mathrm{p}<0.001$ level were taken. Next, we estimated the total soil loss in $\mathrm{Mg} \mathrm{ha}^{-1} \mathrm{yr}^{-1}$ after using the volume differences $\left(\mathrm{m}^{3}\right)$ of soil. The volumes were calculated by creating an imaginary polygon, which were delimited as the distance between each graft union $(3 \mathrm{~m})$ and the average of point measures (5): $1.4 \times 0.6 \mathrm{~m}$. The height of this polygon corresponded to the distance between the botanic marks and the measured point within the inter-row (Fig. 2e).

Total soil loss was estimated from the erosion-deposition (ER) equation proposed by Paroissien et al. (2010):

$\mathrm{ER}=\frac{V o l x B D s}{S t x A v}$

where the volume (Vol), the total area field (St), the age of the vines (Av; 25 years) and the bulk density data (BDs) were used as inputs. The bulk density of $1.22 \mathrm{~g} \mathrm{~cm}^{-3}$ was taken as the average of the soil samples collected with a steel cylinder $\left(1 \mathrm{~cm}^{3}\right)$ from two depths $(0-5$ and $5-15 \mathrm{~cm})$ and row positions $(\mathrm{n}=7)$. To calculate erosion and deposition discrepancies between the SUM and ISUM, we used averages of each difference in each measurement for the vines. We consider including this average (100 samples) and the total percentage increase of the final result in the erosion-deposition equation ( 1 sample).

We conducted a $t$-test to compare the differences between SUM and ISUM because the data showed a normal distribution and satisfied the conditions of homoscedasticity and independence. We then tested the total estimated values of soil erosion rates from the SUM (200 points) and ISUM (500 points) for normality using the Shapiro-Wilk and equal variance method.

\section{Results}

\subsection{Actual topsoil levels and ISUM maps}

A box plot graphic with the total averages, median and percentiles (5th and 95th) can be seen in Fig. 3. Sedimentation $(+5.96 \mathrm{~cm})$ was predominant on the lower (downslope) vine row, while depletion $(-0.94 \mathrm{~cm})$ was predominant on the upper (upslope) row. Maximum positive (sedimentation) and negative (depletion) values were located on the lower row and were $+21 \mathrm{~cm}$ and of $-15 \mathrm{~cm}$, respectively. The highest depletion level was observed in the middle section of the inter- 


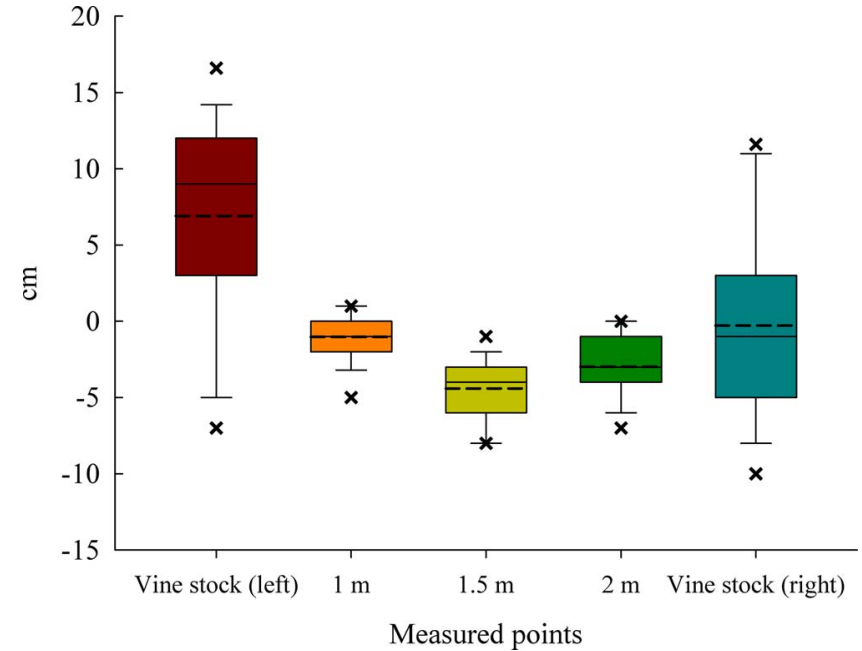

Fig. 3. Box plot graphic of graft union and inter-row measures $(n=500)$. *Continuous line: median; discontinuous line: average; $x$ : 5 th and 95 th percentiles.

row at $-4.05 \mathrm{~cm}$. In the measurement positions 2 and 4 , which were one-meter distance from the vines, average depletion values were $-1 \mathrm{~cm}$ (lower row) and $+2.55 \mathrm{~cm}$

(upper right row). In fact, in the study area, the use of SUM indicated that the vineyards actually received sediment from the upper slope and therefore had a net gain of soil. Contrastingly, ISUM indicated that the vineyards are characterized by high erosion rates due to the lowering of the soil in the inter-row area. Visual inspection showed that the tillage practices caused the soil to accumulate just under the vines, thereby artificially inflating any soil loss estimations gathered from the SUM method, which only measured changes in soil depth in these locations.

Table 1 shows the results of a Mann-Whitney $U$ test of all measured points. The lower row, which was characterized by accumulation of soil, contained the highest measurement variability, followed by the middle row (position 3) and the upper row. Fig. 4 represents the ISUM map made from the 500 measurement points. Detailed analysis of the ISUM map (Fig. 5) lead to assessments of the soil depletion, linear features of soil erosion and soil deposition. The greatest values of soil depletion were found in the areas marked by vines 1-20 (position 1) to 21-40 (position 2). The map also shows linear features reaching negative values of up to $-12 \mathrm{~cm}$ at the same positions. These features are connected to the linear features that have developed in the upper row. Also, most depletion zones are located closely to accumulation sites. On the other hand, the accumulation (green colour) is predominant in the region demarcated by vines $41-81$ (position 3-4), showing a slight increase from the region marked by vines $80-101$ (position 5). Linear erosion features between slope locations clearly showed a connected pattern.

Table 1

All pairwise multiple comparison procedures (Mann-Whitney U Test).

\begin{tabular}{llcc}
\hline Comparison & Diff. of means & $\mathrm{P}$ & Diff. \\
\hline Left side vs Right side & 6.9 & $<0.001$ & Yes \\
Left side vs $1 \mathrm{~m}$ & 6.96 & $<0.001$ & Yes \\
Left side vs $1.5 \mathrm{~m}$ & 10.01 & $<0.001$ & Yes \\
Left side vs $2 \mathrm{~m}$ & 8.51 & $<0.001$ & Yes \\
Right side vs $1 \mathrm{~m}$ & 0.06 & 0.039 & Yes \\
Right side vs $1.5 \mathrm{~m}$ & 3.11 & $<0.001$ & Yes \\
Right side vs $2 \mathrm{~m}$ & 1.61 & 0.397 & No \\
$1 \mathrm{~m}$ vs $1.5 \mathrm{~m}$ & 3.05 & $<0.001$ & Yes \\
$1 \mathrm{~m}$ vs $2 \mathrm{~m}$ & 1.55 & $<0.001$ & Yes \\
$1.5 \mathrm{~m}$ vs 2 & 1.5 & $<0.001$ & Yes \\
\hline
\end{tabular}

*Diff. of means: differences of means in $\mathrm{cm}$.

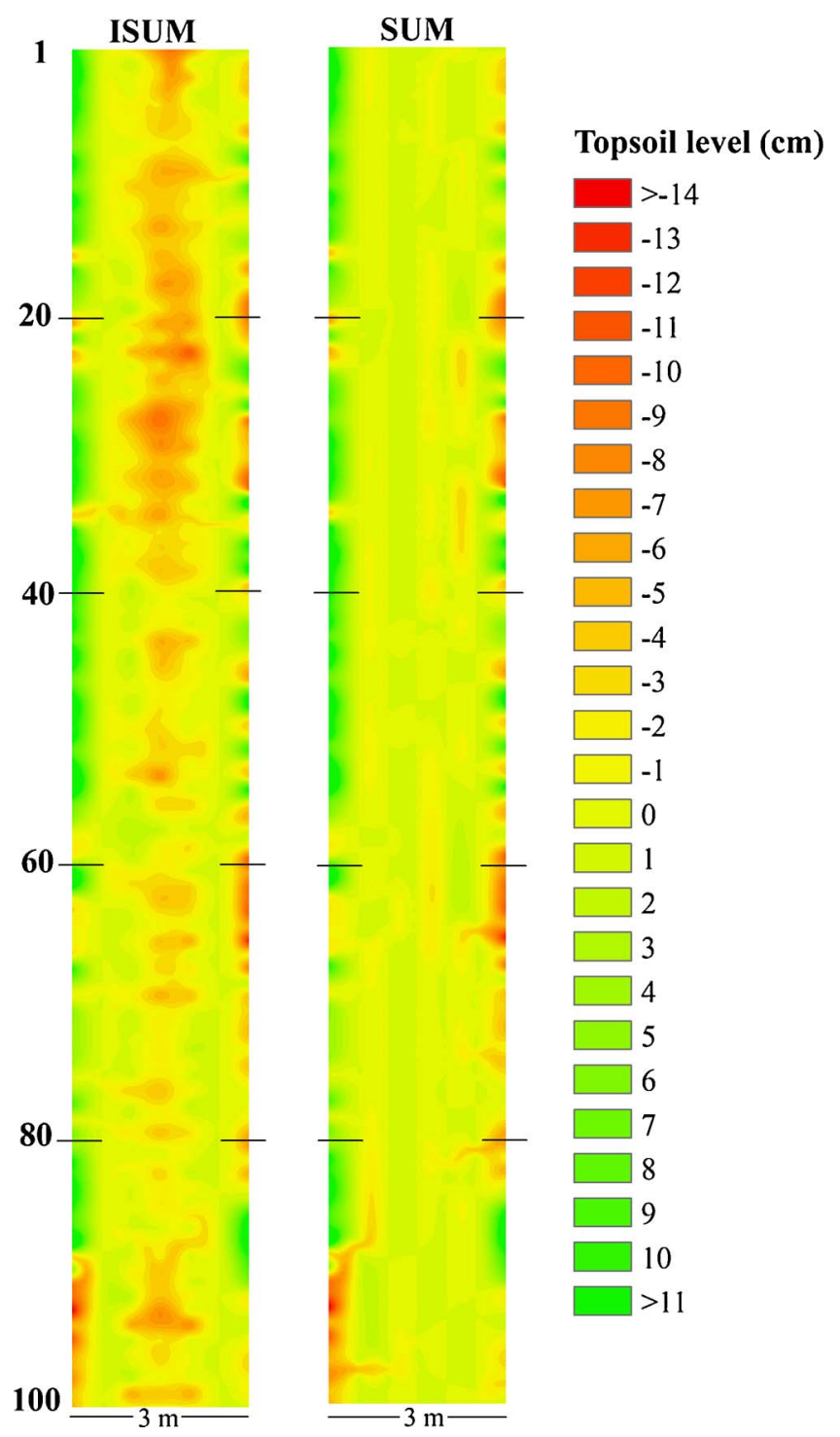

Fig. 4. Topsoil level maps with ISUM and SUM.

\subsection{Soil erosion rates according to ISUM and SUM}

Table 2 shows the results of soil erosion rates calculated from the traditional (SUM) and improved (ISUM) stock unearthing methods. ISUM estimated total soil depletion of $-2.5 \mathrm{Mg}$ ha $\mathrm{yr}^{-1}$ while the SUM actually estimated soil accumulation of $+4.2{\mathrm{Mg} h a ~ \mathrm{yr}^{-1}}^{-1}$ Due to the improved method's inclusion of extra point measurements in the interrow areas, it is possible that the SUM underestimated the soil erosion rates in a total average in every point of about $-25.7 \%$. If we calculate the underestimation of SUM using only the total values of soil depletion/accumulation, we would obtain a value of $-151.4 \%$. Finally, by using a $t$-test, we compared mean values between SUM (200 measured points) and ISUM (500 measured points) and showed a statistically significant difference between the mean values between measurement values in both groups $(\mathrm{p}=<0.001)$.

\section{Discussion}

Gerlach troughs (Biddoccu et al., 2016; Rodrigo-Comino et al., 2017a,2017b), rainfall simulation experiments (Prosdocimi et al., 2017; Rodrigo Comino et al., 2015; Rodrigo-Comino et al., 2016c) or erosion pins (Novara et al., 2011), watershed discharge measurements and modeling (Keesstra et al., 2014) have provided detailed information 

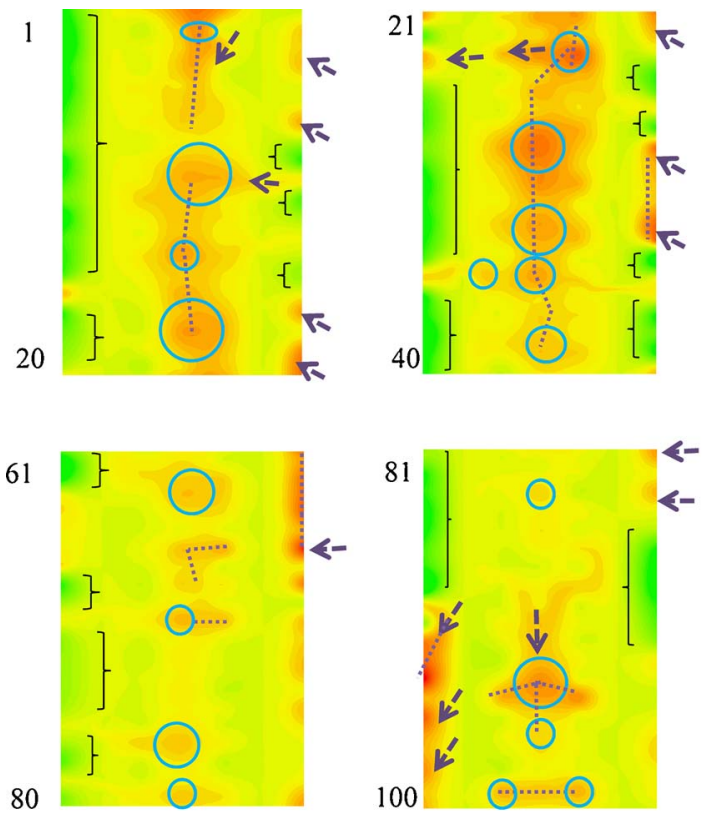

Fig. 5. ISUM map in detail, remarking soil depletion generations, linear features, soil accumulations and sinks.
Table 2

Soil erosion results: comparison between ISUM and SUM.

\begin{tabular}{llll}
\hline Units & ISUM & SUM & Diff. (ISUM-SUM) \\
\hline $\mathrm{m}^{3}$ & -2.2 & +4.2 & +6.4 \\
$\mathrm{Mg} \mathrm{ha}^{-1} \mathrm{yr}^{-1}$ & -2.5 & +4.9 & +7.4 \\
\hline
\end{tabular}

ISUM: improved stock unearthing method; SUM: traditional stock unearthing method; Diff.: Differences between improved and traditional stock unearthing methods.

about short-term erosion rates. However, these methods are usually applied for periods, lasting up to a few years at most (Mekonnen et al., 2017; Masselink et al., 2017a,b). Further, they introduce artefacts into the pedological system which can affect the soil and possibly impact measurement quality. Plots eventually become exhausted of sediment; erosion pins interfere in the splash and overland flow; and rainfall simulation experiments alter the water balance in the soil. On the contrary, because SUM made use of permanent biological markers, it was possible to calculate soil erosion rates without disruption of the vineyard for long-term periods ( $>25$ years). Therefore, we claim that this method should be considered as an important ecological estimator of soil erosion, and further of ecosystem functioning and landscape evolution (García-Ruiz et al., 2017).

On the other hand, we acknowledge some limitations of the method. First, as related to accuracy of the soil loss rates, which are based on low resolution measures $(\mathrm{mm})$ in every graft union and inter-row measurement point. Second, the general assumption that the graft union is always at the same place may in some cases have been violated. Third, we did not take into account the roughness generated by the rock fragments. Fourth, we acknowledge that the ISUM map has only a short-time period of representatively. This is similar to other methods such as drones or photogrammetric surveys. Further, total soil loss estimation calculated by the erosion-deposition equation from Paroissien et al. (2010) which uses area, age of the vines and bulk density as variables (all fixed in the case study), gives only one datum for the whole measuring campaign, with no replication or error bar. Possibly, a future stratification of the sample would generate several datasets for total soil loss and allow the user more options to assess the final results. Finally, the DEM we have developed could not be completely constrained, since we can only mode the relative roughness of the topography higher than $0.5 \mathrm{~m}$ measurement cell only. The last point can be remedied by including extra inter-row point measures.
We demonstrated that the SUM method could be improved by discharging the assumption that the topsoil surface between vine rows remains almost planar. This was supported by visual observation in the field, where high inter-row roughness was identified, plainly indicating areas of depletion and accumulation. This is especially clear in Fig. 6, which shows that soil had accumulated under the vines due to tillage. Additionally, Fig. 6 shows how linear erosion features channeled surface water, artificially creating transport and sink zones. Vineyards are typified by high variability in topography (David et al., 2014; Prosdocimi et al., 2017; Quiquerez et al., 2014). To capture this variability, it was needed to improve the method by adding three measure points within the inter-row. The ISUM obtained higher precision, as we surveyed 5 points instead of 2 each $4.5 \mathrm{~m}^{2}$. This has contributed to a more detailed and accurate soil loss map. We calculated an increased in the total measurement time effort of $\approx 20 \%$. Still, however, the greatest time cost was the act of finding and measuring the location of the graft union.

Our results confirmed that SUM underestimates the soil erosion by $25 \%$, and in some location measurements along the vine rows, by more than $150 \%$. An interesting database could be performed if summarized this $25 \%$ of theoretical underestimation to the final soil erosion estimation of published papers, which is showed in Table 3. If we compare this value of final soil loss of $25 \%$ to those from other published papers (Table 3), we find some interesting discrepancies. For example, using the SUM, Casalí et al. (2009), or Biddoccu et al. (2016) obtained soil

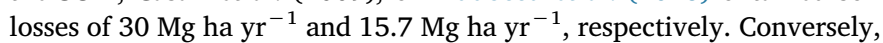
the ISUM would have resulted in much higher soil losses: $+7.5 \mathrm{Mg}$ ha $\mathrm{yr}^{-1}$ and $+3.93 \mathrm{Mg} \mathrm{ha} \mathrm{yr}^{-1}$, respectively. Additionally, in 3-years old vineyards, Rodrigo Comino et al. (2015); Rodrigo-Comino et al.

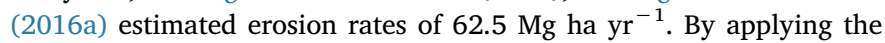
ISUM, it is possible that a more accurate erosion rate of $+15.63 \mathrm{Mg}$ ha $\mathrm{yr}^{-1}$ could have been obtained. A possible explanation for this is that the three years of ploughing did not result in a high accumulation of material underneath the vines. However, these updates are only preliminary approach to the final erosion rate that needs measurements in the field.

The ISUM contributed to a topographical survey which was able to avoid the problems associated with extrapolation of point measurements and the transformation of a DEM (Chevigny et al., 2014; RodrigoComino et al., 2016a). Future research should compare the results from different slope positions (summit, shoulder, back- and footslope), 

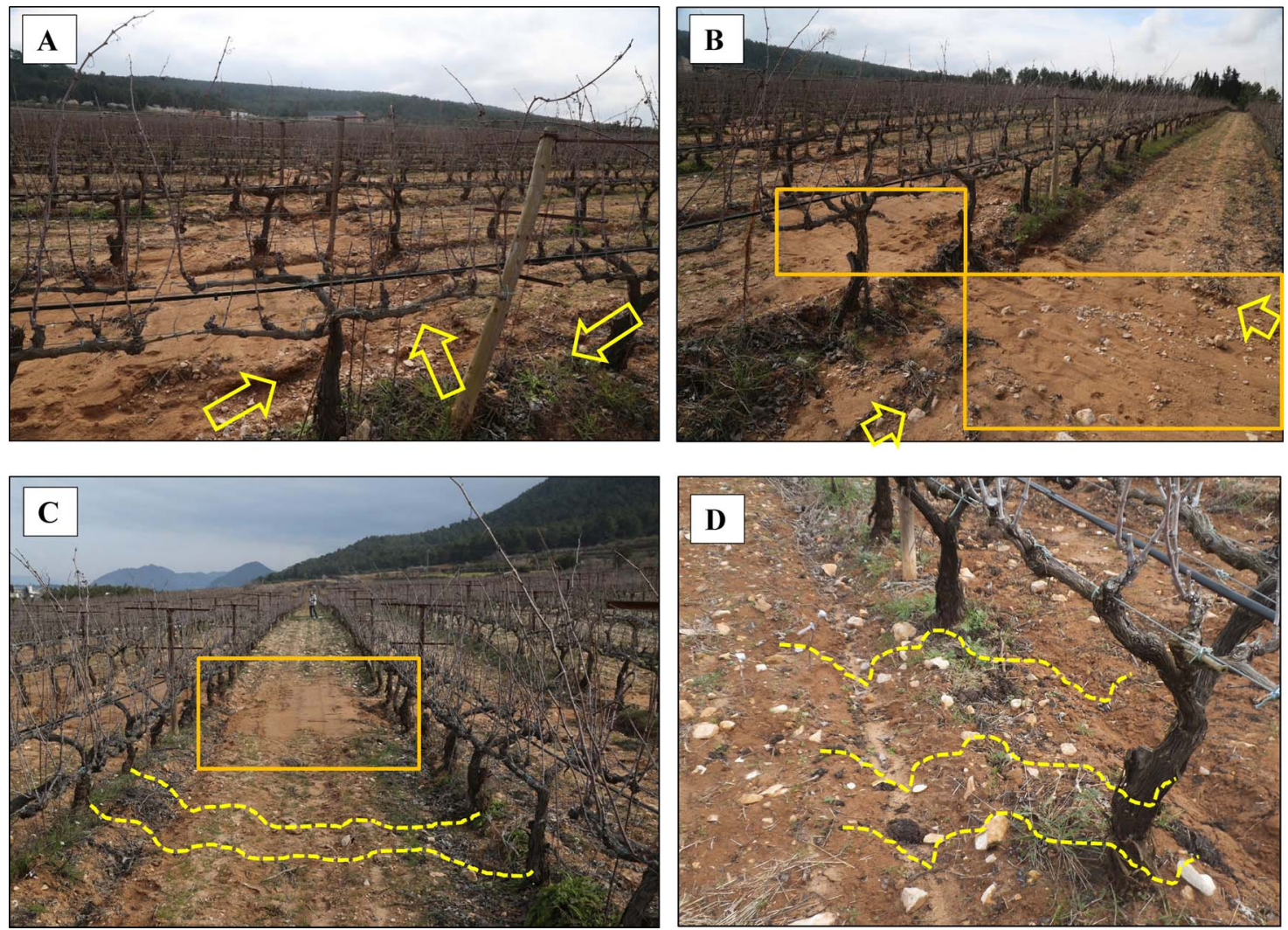

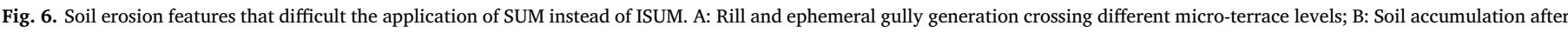

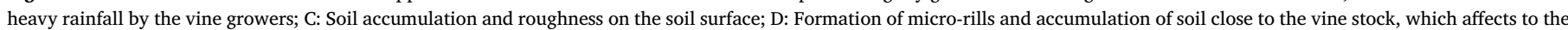
application of traditional SUM.

Table 3

Comparison between SUM and estimated ISUM in recent published articles.

\begin{tabular}{|c|c|c|c|}
\hline Article & Localisation & $\begin{array}{l}\text { SUM (Mg ha } \\
\left.\mathrm{yr}^{-1}\right)\end{array}$ & $\begin{array}{l}\operatorname{ISUM}^{*}\left(\mathrm{Mg} \mathrm{ha}^{-1}\right. \\
\left.\mathrm{yr}^{-1}\right)\end{array}$ \\
\hline $\begin{array}{l}\text { Brenot et al. } \\
\qquad(2008)\end{array}$ & Monthélie, France & 23 & +5.75 \\
\hline $\begin{array}{l}\text { Casalí et al. } \\
\text { (2009) }\end{array}$ & Navarre (Spain) & 30 & +7.5 \\
\hline $\begin{array}{l}\text { Paroissian et al. } \\
\text { (2010) }\end{array}$ & Languedoc, France & 10.5 & +2.63 \\
\hline $\begin{array}{l}\text { Biddoccu et al. } \\
\text { (2016) }\end{array}$ & Aosta valley (Italy) & 15.7 & +3.93 \\
\hline $\begin{array}{r}\text { Rodrigo Comino } \\
\text { et al. (2015) }\end{array}$ & $\begin{array}{l}\text { Ruwer-Mosel } \\
\text { valley (Germany) }\end{array}$ & $3.3^{1}$ & $+0.825^{1}$ \\
\hline $\begin{array}{l}\text { Rodrigo-Comino } \\
\text { et al. (2016b) }\end{array}$ & & $62.5^{2}$ & $+15.63^{2}$ \\
\hline
\end{tabular}

* ISUM: it was simply calculated by adding a theoretical $25 \%$ that ISUM underestimated in our study case after 500 measures.

${ }^{1}$ Old vineyard.

${ }^{2}$ Young vineyard.

different vine ages, different lithologies, before and after tilling or in plots with organic farming. The ISUM method assess the topography and then the connectivity of the flows such as Masselink et al. (2017a,2017b) surveyed, and this information can be also applied at micro-catchments (Vaezi et al., 2017).

Further purely methodological advancements can be made by increasing the number of measured points between the vine rows from 3 to 10 to create a more continuous topographical profile of the soil. This might be accomplished with the use of a laser which would result in maps with $\mathrm{mm}$ resolution. However, that would however increase the cost of the research. Additionally, more measurements from several different rows could better help describe the variability inherent of the measurements and, thus, the uncertainty of the method as such. Our proposal is easy to apply, and it is a cheap method to survey soil erosion in vineyards that probably can be applied in other plantations such as persimmon, orange, almond, apricot or cherry orchards, where the graft union is very clear on the tree stem.

Our research suggested that on sloping terrain $\left(5-10^{\circ}\right)$ in tilled vineyards, soil erosion measured with the SUM underestimated the soil loss rates due to the accumulation of sediments under the vines. However, the vineyards, where herbicide treatments and no-tillage management are used, could have showed different results, such as the ones applying organic farming strategies where catch crops, chipped pruned branches or mulches control the soil erosion rates (Kirchhoff et al., 2017). Probably, the increase in organic matter would result in the swelling of the soil and as a consequence in changes in the soil topography, also varying the final results (Parras-Alcántara et al., 2016).

\section{Conclusions}

The new method developed in this research (ISUM) was a viable method to estimate the long-term (25 years) soil erosion rates in vineyards. It improved over the SUM method in that it is: i) more accurately measured lowering of the inter-row topsoil surface as a consequence of soil erosion due to natural and anthropogenic factors; ii) allowed for topographical mapping of the topsoil, where from flow lines could be drawn and ponding areas, which were clearly identified as a result of extra inter-row measurement points. The erosion rate estimated with ISUM and SUM on the same vineyard were $-2.5 \mathrm{Mg}$ ha $\mathrm{yr}^{-1}$ and $+4.9 \mathrm{Mg}$ ha $\mathrm{yr}^{-1}$, respectively. We concluded that the rates are different by a $25.7 \%$. We suggest applying the new method (ISUM) because the $20 \%$ increase in measurement effort results in a better quality and more accurate dataset, which increases its usability in soil 
erosion control in both vineyards and other orchard agricultural systems.

\section{Aknowledgements}

This research was funded by the European Union Seventh Framework Program (FP7/2007-2013) under grant no. 603498 (RECARE Project). We acknowledge the Winery Celler del Roure and his owner Pablo Calatayud for providing access to the study area. The first author, J. Rodrigo-Comino was issued with a grant for this study under the framework of a short term scientific mission (COST-STSMECOST-STSM-ES1306-010217-081877). We also thank the Bachelor degree and PhD students: Carlos Atienza, Alberto Belenguer, Jorge García Jiménez, José Vicente Vega, Beatriz Stambuck, Jason Davis and Asmare Wubet for the time, efforts and hard work during the field campaign. Jason Davis reviewed and improved the English of the draft manuscript and contributed with excellent suggestions to improve the original idea.

\section{Appendix A. Supplementary data}

Supplementary data associated with this article can be found, in the online version, at http://dx.doi.org/10.1016/j.ecolind.2017.10.042.

\section{References}

Biddoccu, M., Ferraris, S., Opsi, F., Cavallo, E., 2016. Long-term monitoring of soil management effects on runoff and soil erosion in sloping vineyards in Alto Monferrato (North-West Italy). Soil Tillage Res. 155, 176-189. http://dx.doi.org/10. 1016/j.still.2015.07.005.

Biddoccu, M., Zecca, O., Audisio, C., Godone, F., Barmaz, A., Cavallo, E., 2017. Assessment of long-term soil erosion in a mountain vineyard, Aosta Valley (NW Italy). Land Degrad. Dev. http://dx.doi.org/10.1002/ldr.2657.

Blavet, D., De Noni, G., Le Bissonnais, Y., Leonard, M., Maillo, L., Laurent, J.Y., Asseline, J., Leprun, J.C., Arshad, M.A., Roose, E., 2009. Effect of land use and management on the early stages of soil water erosion in French Mediterranean vineyards. Soil Tillage Res. 106, 124-136. http://dx.doi.org/10.1016/j.still.2009.04.010.

Bogunovic, I., Bilandzija, D., Andabaka, Z., Stupic, D., Rodrigo Comino, J., Cacic, M., Brezinscak, L., Maletic, E., Pereira, P., 2017. Soil compaction under different management practices in a Croatian vineyard. Arab. J. Geosci. 10, 1-9. http://dx.doi.org/ 10.1007/s12517-017-3105-y.

Bramley, R.G.V., Hamilton, R., 2004. p.,. Understanding variability in winegrape production systems. Aust. J. Grape Wine Res. 10, 32-45. http://dx.doi.org/10.1111/j. 1755-0238. 2004. tb00006.x.

Brenot, J., Quiquerez, A., Petit, C., Garcia, J.-P., Davy, P., 2006. Soil erosion rates in Burgundian vineyards. Boll. Della Soc. Geol. Ital. 6, 169-173.

Brenot, J., Quiquerez, A., Petit, C., Garcia, J.-P., 2008. Erosion rates and sediment budgets in vineyards at $1-\mathrm{m}$ resolution based on stock unearthing (Burgundy, France). Geomorphology 100, 345-355. http://dx.doi.org/10.1016/j.geomorph.2008.01.005.

Brevik, E.C., Cerdà, A., Mataix-Solera, J., Pereg, L., Quinton, J.N., Six, J., Van Oost, K. 2015. The interdisciplinary nature of SOIL. Soil 1 (1), 117-129.

Calleja-Cervantes, M.E., Fernández-González, A.J., Irigoyen, I., Fernández-López, M., Aparicio-Tejo, P.M., Menéndez, S., 2015. Thirteen years of continued application of composted organic wastes in a vineyard modify soil quality characteristics. Soil Biol. Biochem. 90, 241-254. http://dx.doi.org/10.1016/j.soilbio.2015.07.002.

Casalí, J., Giménez, R., De Santisteban, L., Álvarez-Mozos, J., Mena, J., Del Valle de Lersundi, J., 2009. Determination of long-term erosion rates in vineyards of Navarre (Spain) using botanical benchmarks. Catena 78, 12-19. http://dx.doi.org/10.1016/j. catena.2009.02.015

Cerdà, A., Rodrigo-Comino, J., Giménez Morera, A., Keesstra, S.D., 2017a. An economic, perception and biophysical approach to the use of oat straw as mulch in Mediterranean rainfed agriculture land. Ecol. Eng. 162-171. http://dx.doi.org/10. 1016/j.ecoleng.2017.08.028. 108PA.

Cerdà, A., Keesstra, S.D., Rodrigo-Comino, J., Novara, A., Pereira, P., Brevik, E., GiménezMorera, A., Fernández-Raga, M., Pulido, M., di Prima, S., Jordán, A., 2017b. Runoff initiation, soil detachment and connectivity are enhanced as a consequence of vineyards plantations. J. Environ. Manag. 202, 268-275. http://dx.doi.org/10.1016/j. jenvman.2017.07.036.

Cerdan, O., Govers, G., Le Bissonnais, Y., Van Oost, K., Poesen, J., Saby, N., Gobin, A., Vacca, A., Quinton, J., Auerswald, K., Klik, A., Kwaad, F.J.P.M., Raclot, D., Ionita, I., Rejman, J., Rousseva, S., Muxart, T., Roxo, M.J., Dostal, T., 2010. Rates and spatial variations of soil erosion in Europe: A study based on erosion plot data. Geomorphology 122, 167-177. http://dx.doi.org/10.1016/j.geomorph.2010.06.011.

Chevigny, E., Quiquerez, A., Petit, C., Curmi, P., 2014. Lithology, landscape structure and management practice changes: key factors patterning vineyard soil erosion at metre scale spatial resolution. Catena 121, 354-364. http://dx.doi.org/10.1016/j.catena. 2014.05.022.

David, M., Follain, S., Ciampalini, R., Le Bissonnais, Y., Couturier, A., Walter, C., 2014
Simulation of medium-term soil redistributions for different land use and landscape design scenarios within a vineyard landscape in Mediterranean France. Geomorphology 214, 10-21. http://dx.doi.org/10.1016/j.geomorph.2014.03.016.

De Sy, V., Schoorl, J.M., Keesstra, S.D., Jones, K.E., Claessens, L., 2013. Landslide model performance in a high resolution small-scale landscape. Geomorphology 190, 73-81. http://dx.doi.org/10.1016/j.geomorph.2013.02.012.

Defersha, M.B., Quraishi, S., Melesse, A., 2011. The effect of slope steepness and antecedent moisture content on interrill erosion, runoff and sediment size distribution in the highlands of Ethiopia. Hydrol. Earth Syst. Sci. 15, 2367-2375. http://dx.doi.org/ 10.5194/hess-15-2367-2011.

Dirks, K.N., Hay, J.E., Stow, C.D., Harris, D., 1998. High-resolution studies of rainfall on Norfolk Island: part II: Interpolation of rainfall data. J. Hydrol. 208, 187-193. http:// dx.doi.org/10.1016/S0022-1694(98)00155-3.

Ferrero, A., Usowicz, B., Lipiec, J., 2005. Effects of tractor traffic on spatial variability of soil strength and water content in grass covered and cultivated sloping vineyard. Soil Tillage Res. 84, 127-138. http://dx.doi.org/10.1016/j.still.2004.10.003.

García-Díaz, A., Bienes, R., Sastre, B., Novara, A., Gristina, L., Cerdà, A., 2017. Nitrogen losses in vineyards under different types of soil groundcover. A field runoff simulator approach in central Spain. Agric. Ecosyst. Environ. 236, 256-267. http://dx.doi.org/ 10.1016/j.agee.2016.12.013.

García-Ruiz, J.M., Beguería, S., Lana-Renault, N., Nadal-Romero, E., Cerdà, A., 2017. Ongoing and emerging questions in water erosion studies. Land Degrad. Dev. 28 (1), 5-21.

Goovaerts, P., 1999. Geostatistics in soil science: state-of-the-art and perspectives. Geoderma 89, 1-45. http://dx.doi.org/10.1016/S0016-7061(98)00078-0IUSS (Working Group WRB, 2014. World Reference Base for Soil Resources 2014, World Soil Resources Report. FAO, Rome).

Keesstra, S.D., Temme, A.J.A.M., Schoorl, J.M., Visser, S.M., 2014. A new, simple model for temporal and spatial sediment fluxes in meso-scale catchments: LAPSUS-D: the hydrological functioning. Geomorphology 212, 97-107.

Keesstra, S.D., Quinton, J.N., van der Putten, W.H., Bardgett, R.D., Fresco, L.O., 2016a. The significance of soils and soil science towards realization of the United Nations Sustainable Development Goals. Soil 2 (2), 111-118.

Keesstra, S., Pereira, P., Novara, A., Brevik, E.C., Azorin-Molina, C., Parras-Alcántara, L., Jordán, A., Cerdà, A., 2016b. Effects of soil management techniques on soil water erosion in apricot orchards. Sci. Total Environ. 551-552, 357-366. http://dx.doi.org/ 10.1016/j.scitotenv.2016.01.182.

Keesstra, S., Nunes, J., Novara, A., Finger, D., Avelar, D., Kalantari, Z., Cerdà, A., 2018 The superior effect of nature based solutions in land management for enhancing ecosystem services. Sci. Total Environ. 610, 997-1009. http://dx.doi.org/10.1016/j. scitotenv.2017.08.077.

Kirchhoff, M., Rodrigo-Comino, J., Seeger, M., Ries, J.B., 2017. Soil erosion in sloping vineyards under conventional and organic land use managements (Saar-Mosel valley, Germany). Cuad. Invest. Geogr. 43 (1), 119-140.

Koch, Martin, Andrew, Nash, Robert, 2013. Overview of perceptions of German wine tourism from the winery perspective. Int. J. Wine Bus. Res. 25, 50-74. http://dx.doi. org/10.1108/17511061311317309.

López-Piñeiro, A., Muñoz, A., Zamora, E., Ramírez, M., 2013. Influence of the management regime and phenological state of the vines on the physicochemical properties and the seasonal fluctuations of the microorganisms in a vineyard soil under semiarid conditions. Soil Tillage Res. 126, 119-126. http://dx.doi.org/10.1016/j.still. 2012.09.007.

Leeuwen van, C., Friant, P., Choné, X., Tregoat, O., Koundouras, S., Dubourdieu, D., 2004. Influence of climate, soil, and cultivar on terroir. Am. J. Enol. Vitic. 55, 207-217.

Leonard, J., Andrieux, P., 1998. Infiltration characteristics of soils in Mediterranean vineyards in Southern France. Catena 32, 209-223. http://dx.doi.org/10.1016/S03418162(98)00049-6.

Lourenço-Gomes, L., Pinto, L.M.C., Rebelo, J., 2015. Wine and cultural heritage. the experience of the alto douro wine region. Wine Econ. Policy 4, 78-87. http://dx.doi. org/10.1016/j.wep.2015.09.001.

Marques, M.J., Bienes, R., Cuadrado, J., Ruiz-Colmenero, M., Barbero-Sierra, C., Velasco, A., 2015. Analysing perceptions attitudes and responses of winegrowers about sustainable land management in Central Spain. Land Degrad. Dev. 26, 458-467. http:// dx.doi.org/10.1002/ldr.2355.

Martínez-Casasnovas, J.A., Antón-Fernández, C., Ramos, M.C., 2003. Sediment production in large gullies of the Mediterranean area (NE Spain) from high-resolution digital elevation models and geographical information systems analysis. Earth Surf. Processes Landforms 28, 443-456. http://dx.doi.org/10.1002/esp.451.

Martínez-Casasnovas, J.A., Ramos, M.C., Cots-Folch, R., 2010. Influence of the EU CAP on terrain morphology and vineyard cultivation in the Priorat region of NE Spain. Land Use Policy 27, 11-21. http://dx.doi.org/10.1016/j.landusepol.2008.01.009.

Masselink, R.J., Heckmann, T., Temme, A.J., Anders, N.S., Gooren, H., Keesstra, S.D., 2017a. A network theory approach for a better understanding of overland flow connectivity. Hydrol. Processes 31 (1), 207-220. http://dx.doi.org/10.1002/hyp. 10993.

Masselink, R., Temme, A.J.A.M., Giménez, R., Casalí, J., Keesstra, S.D., 2017b. Assessing hillslope-channel connectivity in an agricultural catchment using rare-earth oxide tracers and random forests models. Cuad. Invest. Geogr. 43, 17-39.

Mekonnen, M., Keesstra, S.D., Baartman, J.E., Stroosnijder, L., Maroulis, J., 2017 Reducing sediment connectivity through man-Made and natural sediment sinks in the minizr catchment, northwest Ethiopia. Land Degrad. Dev. 28 (2), 708-717.

Mol, G., Keesstra, S.D., 2012. Soil science in a changing world. Curr. Opin. Environ. Sustain. 4, 473-477.

Molinero Hernando, F., 2012. Los paisajes del viñedo en Castilla y León: tradición, renovación y consolidación. Polígonos Rev. Geogr. 0, 85-117. http://dx.doi.org/10. 18002/pol.v0i21.27. 
Novara, A., Gristina, L., Saladino, S.S., Santoro, A., Cerdà, A., 2011. Soil erosion assessment on tillage and alternative soil managements in a Sicilian vineyard. Soil Tillage Res. 117, 140-147. http://dx.doi.org/10.1016/j.still.2011.09.007.

Paroissien, J.-B., Lagacherie, P., Le Bissonnais, Y., 2010. A regional-scale study of multi434 decennial erosion of vineyard fields using vine-stock unearthing-burying measurements. Catena 82, 159-168. http://dx.doi.org/10.1016/j.catena.2010.06. 002.

Parras-Alcántara, L., Lozano-García, B., Keesstra, S., Cerdà, A., Brevik, E.C., 2016. Longterm effects of soil management on ecosystem services and soil loss estimation in olive grove top soils. Sci. Total Environ. 571, 498-506.

Prosdocimi, M., Cerdà, A., Tarolli, P., 2016. Soil water erosion on Mediterranean vineyards: a review. Catena 141, 1-21. http://dx.doi.org/10.1016/j.catena.2016.02.010.

Prosdocimi, M., Burguet, M., Di Prima, S., Sofia, G., Terol, E., Rodrigo Comino, J., Cerdà, A., Tarolli, P., 2017. Rainfall simulation and 439 Structure-from-Motion photogrammetry for the analysis of soil water erosion in Mediterranean vineyards. Sci. Total Environ. 574, 204-215. http://dx.doi.org/10.1016/j.scitotenv.2016.09.036.

Quiquerez, A., Chevigny, E., Allemand, P., Curmi, P., Petit, C., Grandjean, P., 2014. Assessing the impact of soil surface characteristics on vineyard erosion from very high spatial resolution aerial images (Côte de Beaune, Burgundy, France). Catena 116, 163-172. http://dx.doi.org/10.1016/j.catena.2013.12.002.

Ramos, M.C., Porta, J., 1997. Analysis of design criteria for vineyard terraces in the Mediterranean area of North East Spain. Soil Technol. 10, 155-166. http://dx.doi. org/10.1016/S0933-3630(96)00006-2.

Rodrigo Comino, J., Lassu, T., González, J.M.S., Sinoga, J.D.R., Seeger, K.M., Ries, J.B. 2015. Estudio de procesos geomorfodinámicos en campos cultivados de viñedos sobre laderas en pendientes en el valle del Ruwer (Alemania). Cuad. Geográficos 54, 6-26.

Rodrigo-Comino, J., Ruiz Sinoga, J.D., Senciales González, J.M., Guerra-Merchán, A., Seeger, M., Ries, J.B., 2016a. High variability of soil erosion and hydrological processes in Mediterranean hillslope vineyards (Montes de Málaga, Spain). Catena 145, 274-284. http://dx.doi.org/10.1016/j.catena.2016.06.012.

Rodrigo-Comino, J., Quiquerez, A., Follain, S., Raclot, D., Le Bissonnais, Y., Casalí, J., Giménez, R., Cerdà, A., Keesstra, S.D., Brevik, E.C., Pereira, P., Senciales, J.M., Seeger, M., Ruiz Sinoga, J.D., Ries, J.B., 2016b. Soil erosion in sloping vineyards assessed by using botanical indicators and sediment collectors in the Ruwer-Mosel valley. Agric. Ecosyst. Environ. 233, 158-170. http://dx.doi.org/10.1016/j.agee. 2016.09.009.

Rodrigo-Comino, J., Iserloh, T., Morvan, X., Malam Issa, O., Naisse, C., Keesstra, S.D., Cerdà, A., Prosdocimi, M., Arnáez, J., Lasanta, T., Ramos, M.C., Marqués, M.J., Ruiz
Colmenero, M., Bienes, R., Ruiz Sinoga, J.D., Seeger, M., Ries, J.B., 2016c. Soil erosion processes in European vineyards: a qualitative comparison of rainfall simulation measurements in Germany, Spain and France. Hydrology 3, 6. http://dx.doi. org/10.3390/hydrology3010006.

Rodrigo-Comino, J., Senciales González, J.M., Ramos, M.C., Martínez-Casasnovas, J.A., Lasanta Martínez, T., Brevik, Ries, E.C., Ruiz-Sinoga, J.B.J.D., 2017a. Understanding soil erosion processes in Mediterranean sloping vineyards (Montes de Málaga, Spain). Geoderma 296, 47-59. http://dx.doi.org/10.1016/j.geoderma.2017.02.021.

Rodrigo-Comino, Brings, C., Iserloh, T., Casper, M.C., Senciales González, Seeger, M., Brevik, E.C., Ruiz-Sinoga, J.D., Ries, J.B., 2017b. Temporal changes in soil water erosion on sloping vineyards in the Ruwer-Mosel Valley. The impact of age and plantation works in young and old vines. J. Hydrol. Hydromech. 65http://dx.doi.org/ 10.1515/johh-2017-0022. (in press).

Salomé, C., Coll, P., Lardo, E., Metay, A., Villenave, C., Marsden, C., Blanchart, E Hinsinger, P., Le Cadre, E., 2016. The soil quality concept as a framework to assess management practices in vulnerable agroecosystems: a case study in Mediterranean vineyards. Ecol. Indic. 61 (Part 2), 456-465. http://dx.doi.org/10.1016/j.ecolind. 2015.09.047.

Smith, M.J., Keesstra, S., Rose, J., 2015. Use of legacy data in geomorphological research. Geo. Res. J. 6, 74-80. http://dx.doi.org/10.1016/j.grj.2015.02.008.

Sofia, G., Tarolli, P., 2017. Hydrological response to $\sim 30$ years of agricultural surface water management. Land 6 (3). http://dx.doi.org/10.3390/land6010003.

Vaezi, A.R., Abbasi, M., Bussi, G., Keesstra, S., 2017. Modeling sediment yield in semi-arid pasture micro-catchments, NW Iran. Land Degrad. Dev. 28 (4), 1274-1286. http:// dx.doi.org/10.1002/ldr.2526.

Vaudour, E., Leclercq, L., Gilliot, J.M., Chaignon, B., 2017. Retrospective 70 y-spatial analysis of repeated vine mortality patterns using ancient aerial time series, Pléiades images and multi-source spatial and field data. Int. J. Appl. Earth Obs. Geoinform. 58, 234-248. http://dx.doi.org/10.1016/j.jag.2017.02.015.

Verheijen, F.G.A., Jones, R.J.A., Rickson, R.J., Smith, C.J., 2009. Tolerable versus actual soil erosion rates in Europe. Earth-Sci. Rev. 94, 23-38. http://dx.doi.org/10.1016/j. earscirev.2009.02.003.

Wahba, G., 1990. Spline Models for Observational Data. Philadelphia: Society for Industrial and Applied Mathematics, Philadelphia, USA.

Wang, K., Zhang, C., Li, W., 2013. Predictive mapping of soil total nitrogen at a regional scale: a comparison between geographically weighted regression and cokriging. Appl. Geogr. 42, 73-85. http://dx.doi.org/10.1016/j.apgeog.2013.04.002. 